\title{
Nasal Hump Correction Using Modified Autospreader Graft: Report of Two Cases
}

\author{
Seung Mun Baek ${ }^{1}$ and Ji Ho Choi ${ }^{2}$ \\ ${ }^{1}$ ID Hospital, Seoul; and ${ }^{2}$ Department of Otorhinolaryngology-Head and Neck Surgery, Soonchunhyang University College of Medicine, \\ Bucheon Hospital, Bucheon, Korea
}

\author{
변형 자가펼침이식술을 이용한 매부리코 교정 2예 \\ 백 승 문 ${ }^{1}$ 최 지 $\overline{ }^{2}$ \\ 아이디병원, ${ }^{1}$ 순천향대학교 의과대학 부천병원 이비인후-두경부외과학교실 ${ }^{2}$
}

\author{
Received April 1, 2016 \\ Revised May 30, 2016 \\ Accepted June 12, 2016 \\ Address for correspondence \\ Ji Ho Choi, MD, PhD \\ Department of Otorhinolaryngology- \\ Head and Neck Surgery, \\ Soonchunhyang University \\ College of Medicine, \\ Bucheon Hospital, \\ 170 Jomaru-ro, Wonmi-gu, \\ Bucheon 14584, Korea \\ Tel +82-32-621-5015 \\ Fax +82-32-621-5016 \\ E-mail handsomemd@hanmail.net
}

It is common to find a nose with a hump, lower nasal tip and a radix among Koreans. A common procedure as an aesthetical improvement for such feature, involves rasping of the hump, while lifting the tip and the bridge at the same time. As for the hump, en bloc resection is a wellknown, traditional surgical method, but it may cause an open roof deformity, which leads to a high possibility of infection if dorsal augmentation using silicone was performed through it as it connects the nasal cavity and dorsum. To overcome this complication, the hump on the bony portion and cartilaginous has been improved by a modified autospreader graft. Also, the graft can also be used for tip-plasty in dorsal augmentation using silicone, septal extension graft, strut and onlay graft. As a result of constant monitoring for a year, the reformation of the hump and infection was not found.

Korean J Otorhinolaryngol-Head Neck Surg 2017;60(7):360-3

Key Words Component hump reduction · Modified autospreader graft · Rhinoplasty.

\section{서 론}

매부리코는 비첨과 비근부를 연결한 선보다 비배가 돌출 되어 보이는 경우로 정의되며, 비골, 상외측비연골 및 비중격 으로 구성되어 있다. ${ }^{1)}$ 큰 비혹을 가진 환자들은 휘어져 보이 기도 하며, ${ }^{2)}$ 인상이 강해 보인다거나 여성의 경우 남성같아 보인다는 이유로 대부분 교정을 원한다. 매부리의 교정방법 에는 크게 일괄 곡비절제술(en bloc humpectomy)과 성분 축 소술(component reduction) 등 2가지 방법이 소개되어 있다. ${ }^{3-5)}$ 동양인의 경우 서양인과는 조금 다르게 국소적으로 돌출 되어 있는 작은 매부리코 환자의 경우에도 낮은 콧대로 인하 여 매부리코 교정과 동시에 융비술을 원하는 경우가 많은데,

This is an Open Access article distributed under the terms of the Creative Commons Attribution Non-Commercial License (http://creativecommons.org/licenses/by-nc/4.0) which permits unrestricted non-commercial use, distribution, and reproduction in any medium, provided the original work is properly cited.
실리콘이나 고어텍스 같은 인공성형물질(alloplastic material) 을 이용하여 융비술을 시행할 때 원하는 미적 개선효과를 얻 기 위해서는 돌출되어 있는 비배(매부리) 부분을 매끈하게 만 드는 것이 중요하다. ${ }^{5,6)}$ 매부리 부분을 제거하는 과정에서 불 가피하게 발생할 수 있는 비강내 점막의 손상 또는 열린 지붕 모양변형(open roof deformity)은 이후 진행되는 인공성형물 질을 이용한 융비술에 대한 감염의 위험성을 높일 수 있다. 따라서, 이에 대한 대비책이 필요하지만 아직까지 확실한 방 법이 거의 알려져 있지 않은 상황이다.

저자들은 펼침이식(spreader graft) 중 최근 소개된 자가펼 침이식(autospreader graft)을 변형한 방법으로 비강내 점막 손상을 예방함과 동시에 매부리 부분을 성공적으로 교정한 후 인공성형물질을 이용한 융비술을 시행한 환자들에서 염 증이나 감염 등과 같은 술 후 합병증 없이 만족할 만한 결과 를 보여 이에 대한 수술 방법 및 경험을 소개하고자 한다. 


\section{증 례}

\section{증 례 1}

23세 여자 환자가 전반적인 매부리(generalized hump)와 낮 은 코끝에 대한 불만을 주소로 내원하였으며, 과거력상 외상 이나 동반질환은 없었다. 이학적 검사상 낮고 처진 코끝 및 비배의 전반적인 매부리를 확인할 수 있었고 비강내 우측으 로 편향된 비중격만곡 소견을 관찰할 수 있었다. 환자에게 매부리코 교정을 위한 변형 자가펼침이식 방법 및 실리콘을 이용한 융비술, 비중격만곡교정과 동시에 비중격 확장 이식편 (septal extension graft)과 비주지주술식(strut), 중첩이식(onlay graft)을 이용한 비첨부 성형술을 설명하고 동의서를 받은 후 수술을 시행하였다.

\section{증 례 2}

25세 남자 환자로 휜 코(외비 만곡), 이에 동반된 매부리와 처진 코끝에 대한 불만을 주소로 내원하였으며, 코막힘 등의 증상도 동반되어 있었다. 과거력상 양악수술을 받은 병력이 있었고 양악수술 후 외비 만곡과 코막힘이 보다 심해졌다고 하였다. 이학점 검사상 전반적인 매부리와 처진 코끝, 골부 및 연골부의 만곡과 동시에 우측으로 편향된 비중격만곡 소 견이 관찰되었다. 환자에게 외비 만곡 교정을 위한 내외측 절 골술, 매부리교정을 위한 변형 자가펼침이식 방법 및 실리콘 을 이용한 융비술, 비중격만곡 교정과 동시에 비중격 확장 이 식편과 비주지주술식, 중첩이식을 이용한 비첨부 성형술을 설명하고 동의서를 받은 후 수술을 시행하였다.

\section{수술 방법 및 결과}

개방형 접근술(open rhinoplasty approach)을 통해 하외측 비연골, 상외측 비연골, 연골성 비중격을 포함한 비배부와 양 측 비골부까지 외비를 구성하는 모든 부분에 대하여 충분한 시야를 확보한다. 큰 비혹(nasal hump)의 경우 연골부 비혹 때문에 시야가 가려져 골막을 박리하는 데 어려움이 있으므 로, 이때에는 중간부분의 골막부터 박리하기보다는 좌우측 의 비골부의 편평한 면의 골막부터 분리하여 중간부분으로 넘어가면 골막 손상 없이 박리가 가능하다. 이후 라습(rasp) 이나 드릴(drill)을 이용하여 목표했던 높이만큼 비혹의 비골 부를 제거한다. 이때 드릴보다는 라습을 더 추천하는데 그 이 유는 라습 시술(rasping)의 술기 자체가 술자의 관찰하에 라 습을 비배부방향으로 눌러 압박함과 동시에 두측-미측방향 (cephalic-caudal direction)으로 왔다갔다하면서 시행되기 때 문에 Rubin절골기를 사용했을 때 발생할 수 있는 비골부의 열린 지붕모양변형을 예방할 수 있기 때문이다. 또한, 종석 부 위(keystone area)를 포함한 비혹 연골부에 생길 수 있는 손 상도 예방할 수 있는 장점이 있다. 계획했던 목표선까지 비혹 의 비골부가 낮춰졌다고 판단되면 이후 변형 자가펼침이식을 시행한다(Fig. 1).

먼저 양측의 하외측 비연골 사이의 막성 중격(membranous septum)을 박리하여 미측 중격(caudal septum)을 찾는다. 그 리고 나서 비배부 방향으로 점진적으로 박리를 진행하며 양 측 비중격에 연골막하 터널(subperichondrial tunnel)을 완 성한다. 양쪽 비중격의 점막연골막피판(mucoperichondrial flap)과 상외측연골을 비중격연골로부터 분리시켜 비중격연 골의 배부를 노출시킨 후 비혹의 비중격연골부위를 비골부 의 높이에 맞춰 메스로 제거를 한다. 분리된 상외측 연골은 비중격연골부보다 높은 위치에 있게 되며, 상외측 연골의 양 측에 두측-미측방향으로 메스로 불완전 절개(incomplete incision)를 넣는다. 이때 비강내 점막에 대한 손상이 없도록 시행하는 것이 중요하다. 이어서 절개된 연골의 내측 부분 (medial part)을 아래쪽, 즉 비강안쪽으로 접어서 넣은 후 양 측을 PDS 5-0으로 봉합을 시행한다. 다음으로 환자와의 상 담에서 목표했던 높이에 맞춰 실리콘과 같은 인공성형물질 을 콧등에 위치시킨 후 움직이지 않도록 봉합사로 고정한다.

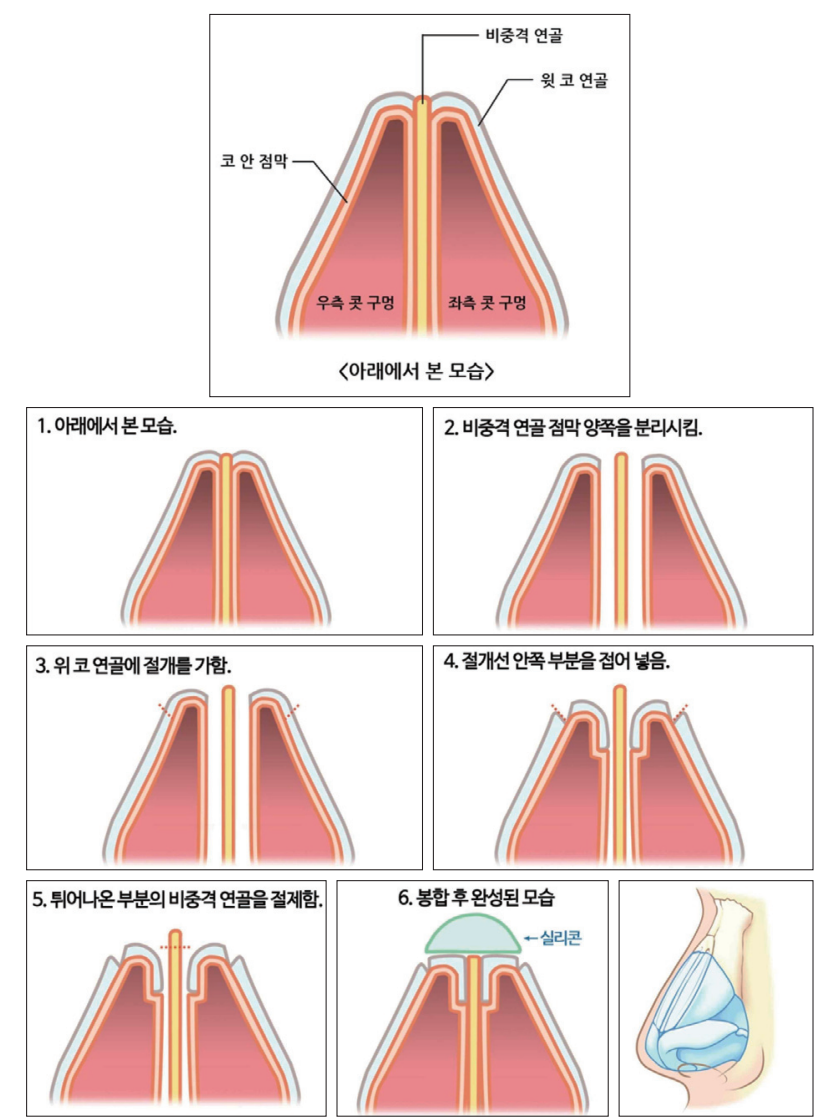

Fig. 1. Schematic images of modified autospreader graft. 

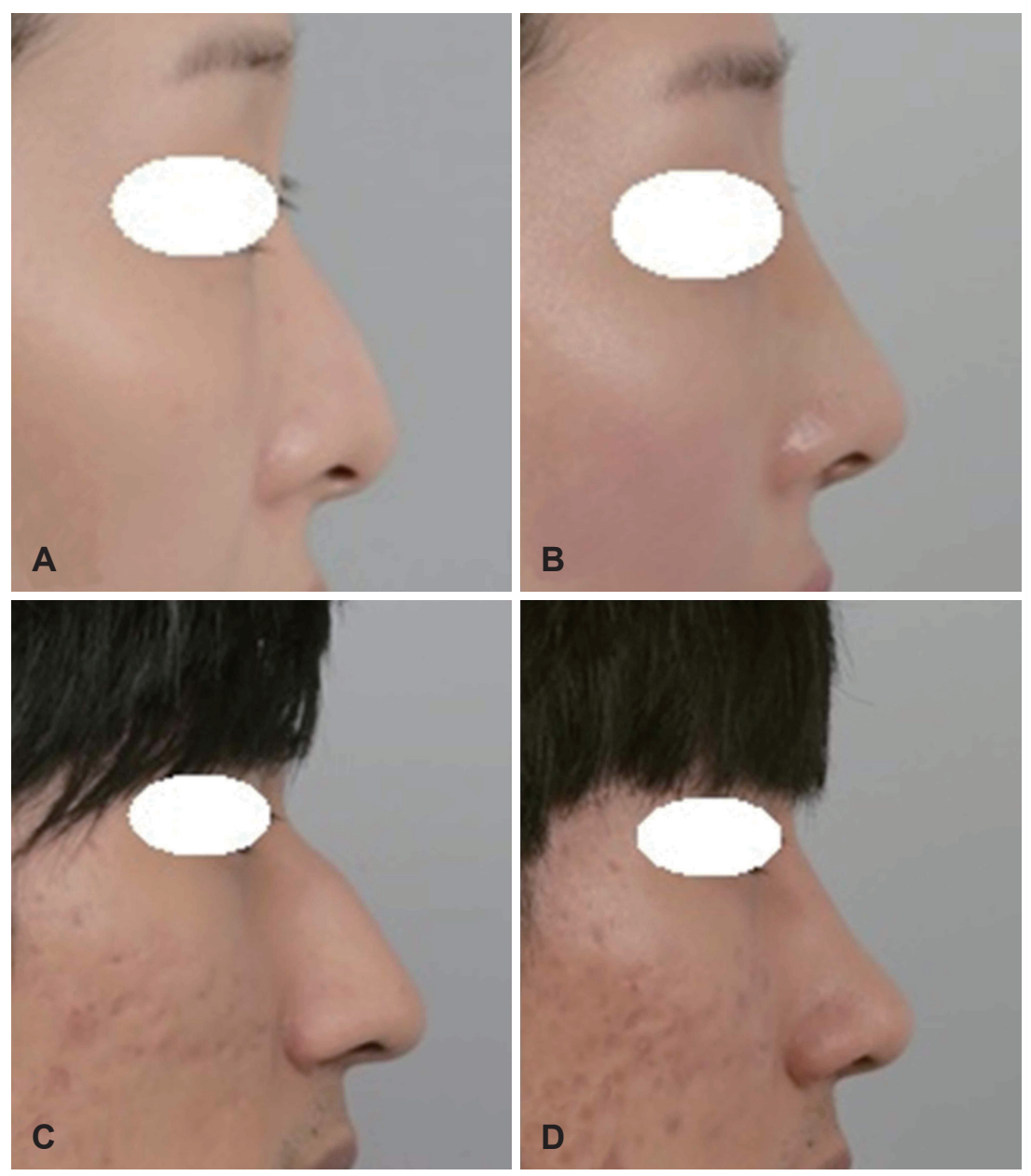

Fig. 2. Pre- and post-operative patient images. Pre-operative image (Case 1) (A). Post-operative image (Case 1) (B). Pre-operative image (Case 2) (C). Post-operative image (Case 2) (D).

필요에 따라 비골부의 좌우 비대칭으로 인하여 외형상 코가 휘어져 보이는 경우에는 절골술(osteotomy)을 시행할 수 있 으며, 코끝을 높일 필요가 있는 경우에는 연장펼침이식, 지주 이식(strut graft), 중첩이식, 모자이식(cap graft) 등을 이용하 여 코끝 성형술(nasal tip plasty)을 시행할 수 있다.

수술 후 모든 환자는 7일째 모든 봉합사를 제거하였고, 수 술 후 1 개월, 12 개월 외래 방문으로 염증발생 여부 및 기타 합병증 유무를 확인하였으나 특이한 소견은 없었다(Fig. 2).

\section{고 찰}

동양인의 매부리코는 대부분 비혹이 작으며 상대적으로 미 간과 코끝이 낮은 것으로 알려져 있다. ${ }^{7)}$ 보통 이러한 동양인 환자들은 미용적으로 돌출된 비배 부분을 없앰과 동시에 전 반적으로 낮은 콧대를 높이려는 경우가 많다. 매부리코 환자 를 수술하는 과정에서 매부리 부분을 제거할 때 술자의 의 도와는 상관없이 때때로 불가피하게 열린 지붕모양변형을 만 드는 경우가 있다. 이렇게 발생된 열린 지붕모양변형을 교정
하기 위해서는 내측절골술을 시행해서 비강 위쪽으로 열린 공간을 닫아줘야 하지만 실제적으로 열린 공간이 완전하게 닫히는 경우가 흔하지 않은 것이 현실이다. 특히, 실리콘 등 의 인공성형물질을 사용하여 융비술을 동시에 계획하고 있는 경우에는 열린 지붕모양변형 자체를 만들지 않는 것이 술 후 염증 발생 가능성을 낮추는 데 도움이 될 수 있다. ${ }^{8)}$

염증은 코성형술 합병증 중 가장 심각한 합병증 중 하나 로, 재수술을 시행하는 흔한 이유 중 하나로 알려져 있다. ${ }^{9)}$ 저 자들은 재수술, 특히 염증 후 발생한 구축코(contracture nose) 교정을 위해 다시 수술을 할 때 많은 경우에서 열린 지붕모 양변형을 관찰함과 동시에 열린 지붕모양변형 주변에서 염증 의 원인으로 생각되는 심한 육아조직(granulation tissue)들 을 발견할 수 있었다. 이러한 소견들을 바탕으로 비강 점막 이 비배부로 노출되지 않으면서 열린 지붕모양변형을 예방할 수 있는 방법을 생각하다가 변형 자가펼침이식방법을 고안하 였다. 이 수술 방법은 상외측 비연골로 펼침이식을 대체할 수 있으므로 그만큼 연골사용량을 줄이는 데 도움을 줄 수 있는 장점이 있다. 실제, 이번 증례들 모두에서 다른 부위의 연골 
채취 없이 비중격 연골만을 이용하여 비중격연장연골술 또 는 지주이식, 비첨이식 등을 동시에 시행할 수 있었다. ${ }^{10,11)}$

이 술식의 또다른 장점은 비강내 점막의 손상이 거의 없고, 일괄 곡비절제술을 시행한 경우와는 다르게 내측 비강 쪽의 점막과 외측 피부 쪽의 표층근건막체계(superficial musculoaponeurotic system)가 완전하게 분리된다는 점인데 내측으 로 접힌 상외측연골이 장벽 역할을 하기 때문이다. 또한, 비혹 의 연골부에 포함되어 있는 상외측연골을 절제하는 것이 아 니라 이를 보존하여 펼침이식처럼 이용할 수 있어 중격의 안 정성에도 도움이 되며, 비혹 제거 후 비배부의 윗면이 편평해 지고 연골로 지지되는 효과가 있어 비배부에 인공성형물질 을 이용하여 융비를 동시에 시행했을 때 사강(dead space)이 거의 발생하지 않는 등 여러 가지 장점이 있는 것으로 생각된 다. 이러한 방법으로 수술한 환자들을 12 개월간 추적 관찰 했을 때 염증이 발생된 경우는 관찰되지 않았는데, 인공성형 물질과 비강내 점막이 서로 연결되지 않은 것이 가장 큰 이유 로 사료되었다. 아울러, 수개월 이후에도 발생할 수 있는 구축 현상도 거의 없었는데, 아마도 인공성형물질의 아랫면이 맞 닿는 비배부 윗면이 인공성형물질을 잘 지지하여 인공성형 물질의 휘어짐 또는 변형 가능성을 낮춘 것이 한 가지 이유로 생각되었다. 하지만 염증, 감염, 구축현상은 그 이유가 다양하 고 또, 두 케이스의 경우로 단정짓기에는 무리가 있다고 판단 되며 향후 더 많은 수술 증례와 장기간의 추적 관찰이 필요 할 것으로 사료된다. 본 술식에도 몇 가지 단점이 있을 수 있 다. 우선, 기존의 방법보다 시간이 더 걸릴 수 있고, 수술에 익 숙해지기 위해서는 어느 정도 경험이 필요할 수 있으며, 아직 까지 본 수술 방법에 대한 수년 이상의 장기간 추적 관찰 결 과가 없다라는 점이다. 이에 대해서는 향후 관련 연구들이 필 요할 것으로 생각된다.

결론적으로, 매부리코 교정 및 종석 부위 보강(reinforce- ment)을 위해 양측 상외측연골을 이용한 변형 자가펼침이식 을 시행 받은 환자들을 분석한 결과 수술에 대한 만족스러 운 성과를 얻을 수 있었다. 따라서, 매부리코 교정술 및 인공 성형물질을 이용한 융비술을 시행할 때 술 후 염증에 대한 위험 가능성을 낮추기 위해서는 상외측연골과 비골부분까지 일괄적(en bloc)으로 제거하는 방법을 시행하기 앞서 변형 자 가펼침이식을 먼저 고려하는 것이 좋을 것으로 사료된다.

\section{REFERENCES}

1) Sullivan MJ, Krause CJ. Surgery of the bony and cartilaginous dorsum. Otolaryngol Clin North Am 1987;20(4):825-35.

2) Jang YJ, Kim JH. Classification of convex nasal dorsum deformities in Asian patients and treatment outcomes. J Plast Reconstr Aesthet Surg 2011;64(3):301-6.

3) Ishida J, Ishida LC, Ishida LH, Vieira JC, Ferreira MC. Treatment of the nasal hump with preservation of the cartilaginous framework. Plast Reconstr Surg 1999;103(6):1729-33; discussion 1734-5.

4) Rohrich RJ, Muzaffar AR, Janis JE. Component dorsal hump reduction: the importance of maintaining dorsal aesthetic lines in rhinoplasty. Plast Reconstr Surg 2004;114(5):1298-308; discussion 1309-12.

5) Arslan E, Aksoy A. Upper lateral cartilage-sparing component dorsal hump reduction in primary rhinoplasty. Laryngoscope 2007;117 (6):990-6.

6) Hussein WK, Elwany S, Montaser M. Modified autospreader flap for nasal valve support: utilizing the spring effect of the upper lateral cartilage. Eur Arch Otorhinolaryngol 2015;272(2):497-504.

7) Jin HR, Won TB. Nasal hump removal in Asians. Acta Otolaryngol Suppl 2007;(558):95-101.

8) Jung YG. Tailored Correction of Deviated Nose. Korean J Otorhinolaryngol-Head Neck Surg 2013;56(11):684-91.

9) Agrawal KS, Bachhav MV, Naik CS, Gupta S, Sarda AV, Desai V. "Ride-on" technique and other simple and logical solutions to counter most common complications of silicone implants in augmentation rhinoplasty. Indian J Plast Surg 2015;48(2):172-7.

10) Sheen JH. Spreader graft: a method of reconstructing the roof of the middle nasal vault following rhinoplasty. Plast Reconstr Surg 1984; 73(2):230-9.

11) Kim JS, Yu KK. Correction of hump nose considering the characteristics of Korean nose. Korean J Otorhinolaryngol-Head Neck Surg 2014;57(12):815-20. 